Винниченка.

Наукові інтереси: методика викладання

іноземних мов у школі.

Department of Linguodidactics and Foreign Languages, Volodymyr Vynnychenko Centralukrainian State Pedagogical University.

Circle of scientific interests: methodology of

INFORMATION ABOUT THE AUTHOR

KAPITAN Tetiana Anatoliivna - Candidate of

Philological Sciences, Associate Professor, foreign language teaching in school.

Стаття надійшла до редакиії 09.02.2021 p.

УДК 821.111 (73) - 311.1.09

DOI: 10.36550/2415-7988-2021-1-192-80-84

КОЗІЙ Ольга Борисівна -

кандидат філологічних наук,

доцент кафедри лінгводидактики та іноземних мов

Центральноукраїнського державного педагогічного університету

імені Володимира Винниченка

ORCID:https://orcid.org/0000-0002-9478-9502

e-mail: olykaaaa@gmail.com

\title{
STUDYING THE ARTISTIC DETAIL (based on Donna Tartt's novel «The Goldfinch»)
}

Formulation and justification of the urgency of the problem. At the classes of English and American Literature the students are to be forced to analyze the artistic detail as it's the best way to understand the author's idea. For the students of non-philological departments the best analytical method is «in succession to the author». Donna Tartt's novel The Goldfinch (2013) was taken as an example.

The novel is told in retrospective firstperson narration by Theodore Decker, who tells the story of his life thus far. The novel has been an international bestseller, spending over thirty weeks on the New York Times bestseller list in the U.S. and on the Sunday Times hardcover fiction bestseller list in the UK. It has had the same success in translation, debuting at number one in France in January 2014.

The scientific novelty of the article consists in an attempt to show the ways of analysis of the novel as a literature phenomenon. This novel is extremely deep and multifaceted and provides opportunities for analytic study. This research is devoted to the analysis of the second chapter of the novel in which the writer reveals herself as a good psychologist. That is why the theories of J.Mill [4] are to be taken into account while analysing.

Analysis of recent research and publications. The publishing of the Russian translation was followed by a detailed review of the translater V. Babytskaya [1]. Her analytical review places D.Tartt's novel among classical novels, such as of C.Dickens', F.Dostoyevskiy's, T.Mann's, J.Rowling's and others. The researcher traces the main problems of the novel and skilfully compares the characters of The Goldfinch with those of the world's most significant pieces of fiction.

The research methodology is based on a combination of principles and methods of scientific work.

This novel is extremely deep and multifaceted and provides opportunities for analytic study. This research is devoted to the analysis of the second chapter of the novel in which the writer reveals herself as a good psychologist. That is why the theories of J.Mill [4] are to be taken into account while analysing.

The main material of the study. The Goldfinch is a story of a boy and later an adult male Theodore Decker who accidentally obtains a masterpiece. The framing of the work is a story about staying the protagonist in Amsterdam. Theo appears to the reader as an adult man, who at Christmas time came to Holland.

In the second chapter of the first part D.Tartt reveals herself as a skilful psychologist. She skilfully accustoms herself to the inner state of the main character, with him she travels through the memories, tracks associative relationships he makes. The writer brilliantly follows all defence mechanisms of a man who is faced with the inevitability. The previous chapter concludes with an optimistic confidence of the protagonist that his mother may be alive as she hasn't been found among the dead. So Theo is returning home to wait for her there. This reaction at first glance seems illogical because the boy ought to look for her some more, to ask the people. However, in the state of emergency the psyche uses own protective mechanism - tries to follow the established procedures. 
The writer skilfully transmits herself through the emotions of the main character in three ways: as an adult who is - again and again - going through the critical day of his life, a 13year-old teenager who has just survived the shock, looked into the face of death, and a child who cannot wait until his mother's coming home. D.Tartt addresses to a number of psychological techniques in which people unconsciously manage to escape, to avoid panic in a difficult situation. She embodies into two main hypostases of the character - of a teenage boy and adult - simultaneously, in great detail the writer describes the rules of the game Theo Dekker played with himself.

The writer accentuates visual detail with auditory ones that result into vivid and living intussusceptions of a stressful psychological situation. Thus when the mother was much late the boy (as he mentioned), «like all abandoned puppy» [3] was sitting at the front door listening whether the elevator was rising.

With the help of image and detail gradation the author grows the tension of boy's expectations: children's fears that the mother cannot return because of something (a child does not need to establish the causation) in Theo's memories turn into rather clearly represented. In primary school he (the author insists) feared for his mother almost every day. D.Tartt depicts a real child of a media century who, being overinformed without proper understanding of events, becomes an adult (but not psychologically) too quickly. Being under influence of what he has heard and seen and according to general media impact, the main character designs almost all possible tragic events that can happen with his mother.

The author describes the life of the family, in a few paragraphs skilfully depicting the pain of the child and the mother who had to suffer from the alcoholic. Then there follows Theodor's confession to himself of how his father left the family. The author notes that it was a great relief for the mother and son. The changes in the family hierarchy can be traced via detail: «The photo with a tanned young father on the slopes for skiing has quietly disappeared from the wall, while there was a photograph of my mother and me on the rink in Central Park» [3].

The writer skilfully conveys the depth of character and his experience, his various feelings, describing how the boy was trying to persuade himself that his mother had survived. Theodore «switched on» some other emotions, recollecting a red-haired girl from the exhibition. Pippa, whose face remained with the main character and was carried through his life, actually saved him, having kept him for a few minutes at the exhibition. Theo did not abandon hope that a wounded old man, whom he had seen in the museum with Pippa, survived. The writer depicts panic condition in which a person is trying to convince oneself that everything is in order.

The chosen way of analysis «in succession to the author» is the best way to follow all the details of writer's skill. She leads the main character (and the readers together with him) along the streets, dives into memories, shows his strained senses, makes him feel the smallest raindrops on the face, dizziness as a result of the accident. The image of the house, as it has been mentioned, has got a powerful archetype meaning. It is seen as a combination of artistic details - the author creates not only alive, relief image of the apartment, and even the corridor where appropriate smells and bleak colours surround the boy.

The emotional tension portrayed increases when the art world is localized in the flat of the character. Apparently, the most important semantic accent (combined with bitter irony) falls on the boy's appeal to his mother, especially because it becomes rhetorical: the boy calls his mother, but doesn't hear the answer. The mentioned appeal transforms into a question, then - into a tragic refrain accentuated by author remarks. After seeing the apartment, Theo calls his mother again: «Mom? - I called with visible panic crack in my voice» [3]. The author uses the method of internal call - not a monologue, but a conversation (inner) between the main character and his mother, represented by the messages left by the son. D.Tartt appeals to interesting bitterly ironic comparison of the obsessive thoughts of a mother with a purple cow from a kid's rhyme.

The author uses gradation way of describing while stringing visual and auditory details, retards artistic time when Theo comes into the room and freezes there. The author uses the method of a magnifying glass: she carefully examines all things, giving a special semantic loading to visual details with the particle «no»: those which were expected to be there (as they were an integral part of normal everyday life) but weren't, disappeared together with boy's tranquillity. So the details transform routine image of the artistic space into a tragic one: «There were no keys of hers on the hook by the door, there was no bag on the table» [3]. A teenager, being panic-stricken, grabs the slightest traces of memory, for example, turns attention to mother's cup with print of her lipstick and the remnants of cold coffee. Such visual, as they may be called, non-details are 
accentuated by audio ones: there were no messages on the phone.

Emotional stress of the child is accentuated by physical pain he feels: as after the explosion Theo suffers from headaches.

The author uses gradation while describing the changing of the main character's emotional state, noting that he got home as if using internal reserves of hope. But when his expectations were not fulfilled he was caught by weakness: he could hardly move, it took him much pains to concentrate. Then comes fear and panic which is veiled by the mind that the gas had been left turned the kitchen.

The author depicts boundary condition of the boy. Despite pain and weakness, all his senses and feelings were sharpened, he was tracing all the slightest sounds, the mind was trying to find some logical explanation of the situation and the ways solution.

The writing of $\mathrm{D}$. Tartt is characterized by the unique skill in the detail describing: the author makes the reader not only empathize Theo but feel what he feels. So the details become relief. The inner discomfort (if fear and panic can be summarized into such concept) of the main character is emphasized by physical discomfort: «I fell asleep as I was - in dirty and wet clothes, bed was also wet, where I lay there remained a wet hollow» [3].

The increase panic results into the following effect: Theo is puttering around the apartment, turning on all the lights. The writer notices subtle features of a child's psychology (because he was still a child): the fear of the unknown is transformed into the fear of the dark with all the hidden horrors and challenges.

The message on the answering machine brings Theo bitter disappointment: the boy expected to hear a human voice to break the circle of his lonely silence. And then comes the painful disappointment because the voice does not belong to his mother.

The writer compares two artistic worlds within the artistic world of the novel: the microcosm of Theo's apartment with retarded artistic time and macrocosm (the world in general) with normal temporal characteristics. There are some remnants of hope for the boy to live within the microcosm of home (the place of defence) while the macro exists according to its own inexorable laws. The message not from his mother breaks a thin protective shell. At the same time, the main character, who already feels what has happened, destroys this protection completely. This destruction and the fusion of two worlds is traced with the assistance of details: the boy opens the curtains, looks out and faces the world that continues to live, the world full of sounds and movement. Then the world breaks into the unreliable shelter of a lonely child brining vanity, sounds, smells of life, people, families, animals, events. The boy is wrapped by all these as before - by silence. Stringing visual and auditory images and details of syntax is represented in the form of period - a syntax construction, which is logically and intonationally divided into two unequal parts: the first is a list of grammatical phenomena, in which the tone gradually increases, the other coming after a pause - is accompanied by a decrease in tone and is in some relations with the first (temporal, causal, opposite, etc.). The first part may be represented as a number of similar subordinate clauses, a number of similar members, and the parts are generally constructed using syntactical parallelism [2]. The second part of the given period is a rhetorical question and refrain: «Where is she?» [3].

The writer appeals to intertemporal overlapping memories in the form of opposition, as well as a small Theo invented tragedies that could happen to the mother, so Theo as a teenager was looking for reasons that could delay it. There is an internal dialogue between almost illusory hope and logic. D. Tartt skilfully depicts the boy overwhelmed with panic and almost hysterics using mentioned details: the noise of the evening bustle contrasts with the silence of the empty apartment, Theo was seeking for help at home, looking for hope to solving the situation, looking for a note, which mom could leave but did not find it. Theo was waiting for the mother, already knowing that it was useless. The boy obviously goes beyond the borders of the microcosm in search of moral support, so he calls a concierge. Then he dare for more: he switches on the $\mathrm{TV}$ and understands the reality of recent events. He even notes the number of a telephone hotline and makes an agreement with himself to call if the mother does not appear in half an hour. The fact that he has made at least this step reassures Theo: he believes that due to his actions mom may return faster. The boy hopes that number will remain unused. But the mother did not come and after five minutes Theo dared to dial a number. The description of the call is characterized by the separation of artistic world of the novel: empty advertising heard from the TV - that's a world-background and a teenager with a handset becomes the embodiment of nervous expectation. Occasionally during a conversation with the social worker this background breaks into Theo's world by separate remarks, as if the big world tries to conduct a dialogue with the main character, strengthens the fluidity of life outside. However, 
the life stopped in the apartment. The news that the mother was not in the list of victims, initially encouraged Theo, but the tension did not leave the boy.

The writer again uses intertemporal parallelism: the boy fulfils some calculations. Having heard that twenty-one people were killed, Theo tries to estimate the measure of the tragedy. The boy tries to imagine that enormous quantity: «Twenty-one people - a half empty cinema, or, for example, a bus; in my English class there were three people more». Such calculations turn into panic that the boy can barely hold. The writer shows how a teenager who's wanted to be independent, becomes a frightened little child, ready to shout «Mom!» [3].

He finds the rescue from panic within the planned actions, within the agreement between him and his mother: just after the accident he does not search for her but goes home to wait there, because it was customary in the family, it was their agreement. Main character's absorption in own thoughts and the remains of hope is emphasized by the retarded artistic time: the boy saves himself in the memories and everyday actions.

Frozen artistic time and space are interrupted by absurd dynamic element - which is the call to the hotline and talk with a social worker. Theo is trying to make his own corrections of this unreal reality, so while talking he was looking in search of unique psychological rescue boats - mother's things. He tries to move away from heavy anticipation and senseless talk with an indifferent person. The original rescue the boy finds is in the physical sensation when he realizes he is hungry. But he doesn't stop thinking about mom so leaves meal for her, cleans the kitchen, because it will be pleasant for her, fixes the drawer. In the drawer he finds only some useless rubbish. He's wasted time trying to open so his waiting for mom was also fruitless.

Art time is stretched, just as when Theo has just crossed the threshold of the house, he dives into sounds, immersed in himself, actually listening to the sounds of heartbeat of the house and the city. Again the writer resorts the contrast between two worlds: the main character notes fluidity, life of the world, day and night, everyday chores, people around, who seem almost aliens. At the time Theo himself seems to be frozen with a single question: «What will I do?» [3].

With the help of artistic detail the author conveys the way the main character is presided beyond the objective perception of the world: «The flat was blurred, there was a circle of light around the lamp which was trembling like a halo»" [3].

The next element the author uses is a gradation, but descending: the boy, his heart fading, runs to open the door, shouting «Mom!». Having opened he faces inevitability. The writer approaches to bright metaphor to emphasize the descending gradation: «My heart flew down counting the floors».

Using detailed description of social workers who appeared on the doorstep to destroy what remained from boy's hope and expectation helps the author to retain associative narration: «Seeing them, I realized that my life as it was before that very minute was over» [3].

Conclusions and prospects for further researches of directions. Thus, in the novel The Goldfinch D. Tartt declares herself a talented master of words, subtle psychologist and philosopher. As a surgeon, the writer separates one second of expectation from the other, detail from detail. Therefore, the reader can observe not just a frightened child but deep sorrow of the loss of the whole world. This is achieved by the skillful combination of visual and auditory details that create convex emotionally saturated images filled with heartbeat of life. The author dowers the main character - both a teenager and an adult man - with the ability to see deep philosophical maxims in small details, to decipher the message from the artist, to understand the dialectical interpenetration of life and death. Because of such careful author's treatment to the artistic time and space the most appropriate way to study seems to be the analysis «in succession to the author».

\section{СПИСОК ДЖЕРЕЛ}

1. Бабицкая В. «Щегол» Донны Тартт: время ничего не значит. Изд-во Corpus, Москва, 2014, перевод А. Завозовой.

2. Мельник Т. Образність художнього тексту через призму лінгвістичного аналізу. Севастополь, 2005 // URL: www.ukrlife.org/main/minerva/melnyk_lingvo.doc.

3. Тартт Д. Щегол: Роман // URL: www.nemaloknig.info.

4. Mill, J. S. 1843. A System of Logic Ratiocinative and Inductive: Being a connected view of the Principles of Evidence and the Methods of Scientific Investigation, cited from The Collected Works of John Stuart Mill, Volumes 7 (Books I-III), 8 (Books IV-VI), J.M.Robson (ed.), London and Toronto: Routledge and University of Toronto Press, 1973, 1974.

5. NU. 2013. Donna Tartt - Het puttertje.

\section{REFERENCES}

1. Babytskaya, V. (2014). «Schegol» Donnyi Tartt: vremya nichego ne znachit. [The Goldfinch by Donna Tartt: Time does not mean anything]. Moscow. 
2. Melnyk, T. (2005). Obrazy khudozhnoi liteteratury $v$ svitli lingvistychnoho analizu. [Literary text images in the light of linguistic analysis]. Sevastopol.

3. Tartt, D. Shhegol: Roman [Donna Tartt. The Goldfinch] // www.nemaloknig.info. (in Russian)

4. Mill, J. S. (1843). A System of Logic Ratiocinative and Inductive: Being a connected view of the Principles of Evidence and the Methods of Scientific Investigation, cited from The Collected Works of John Stuart Mill, Volumes 7 (Books I-III), 8 (Books IV-VI), J.M.Robson (ed.), London and Toronto: Routledge and University of Toronto Press, 1973, 1974.

5. NU. 2013. Donna Tartt - Het puttertje.

ВІДОМОСТІ ПРО АВТОРА

КОЗІЙ Ольга Борисівна - кандидат $\begin{array}{lrrr}\text { філологічних } & \text { наук, } & \text { доцент } & \text { кафедри } \\ \text { лінгводидактики } & \text { та } & \text { іноземних } & \text { мов }\end{array}$

Центральноукраїнського державного педагогічного університету ім. В. Винниченка.

Наукові інтереси: проблеми викладання англійської мови; літературний процес $\mathrm{XX}$ століття.

\section{INFORMATION ABOUT THE AUTHOR}

KOZII Olha Borysivna - Ph.D., associate professor Department of Philology and Journalism Centralukrainian State Pedagogical University named after V. Vynnychenko

Circle of scientific interests: the problems of studying English; the literature of the XXth century.

Стаття надійшла до редакиії 20.01.2021 р.

УДК: 373.2.(091)(477)

DOI: 10.36550/2415-7988-2021-1-192-84-88

КОСТЕНКО Лариса Давидівна кандидат педагогічних наук, начальник Управління освіти Міської ради міста Кропивницького ORCID:https://orcid.org/0000-0003-2930-7404 e-mail: shkoda44@ukr.net

\section{АКТУАЛІЗАЦІЯ ДОСВІДУ ОРГАНІЗАЦЇ̈ ПОЗАШКІЛЬНОЇ ОСВІТИ В УКРАЇНІ (1952-1991рр.) ТА ЙОГО ВИКОРИСТАННЯ В СУЧАСНИХ УМОВАХ}

\begin{abstract}
Постановка та обгрунтування актуальності проблеми. Серед соціальних інститутів виховання й розвитку підростаючих поколінь особлива роль належить позашкільній освіті. Вона $\epsilon$ невід'ємною частиною соціуму, що сприяє реалізації індивідуальних психофізичних i соціальних потреб особистості яка розвивається, розкриттю її творчого потенціалу, формуванню соціально значущих якостей.

Досвід позашкільної освіти попередніх років має стати цінним джерелом для пошуку нових підходів до вдосконалення освітнього процесу в закладах позашкільної освіти. Об'єктивний історико-педагогічний аналіз теорії і практики розвитку позашкільної освіти, теоретичне узагальнення цінного досвіду діяльності позашкільних закладів, творче використання педагогічних ідей минулого 3 урахуванням сучасних вимог i можливостей держави, дають змогу якісно оновити й удосконалити зміст позашкільної освіти України.
\end{abstract}

Аналіз останніх досліджень i публікацій. Історичні основи становлення i розвитку закладів позашкільної освіти розкрито в роботах В. Береки, С. Букрєєвої, О. Глух, Т. Цвірової, А. Шепілової та ін.
Мета статті - виокремити прогресивні ідеї досвіду організації позашкільної освіти України в радянський період, які заслуговують на осмислення в контексті їх впровадження в закладах позашкільної освіти в сучасних умовах.

Виклад основного матеріалу дослідження. У період переходу України до ринкових відносин постало питання про розробку нових підходів до розвитку позашкільної освіти дітей. Це зумовлюється низкою факторів.

По-перше, економічна i політична нестабільність соціокультурних систем, що сформувалися упродовж останніх десятиріч, дестабілізація шкільної системи освіти, посилення негативної дії стихійних різновекторних чинників, залишковий принцип фінансування закладів позашкільної освіти призвели до зниження ефективності позашкільної освіти та до занепаду їхньої навчально-матеріальної бази, що в результаті суттєво заважає повною мірою використати унікальні можливості системи позашкільної освіти учнівської молоді України.

По-друге, одноманітність організаційних форм, зайве регламентування, формалізм освітнього процесу, недостатне врахування потреб i різнобічних інтересів молоді, а також ігнорування регіональних можли- 